\title{
Investigation of the thermal conductivity and flexural strength of polymethylmethacrylate denture base material with $\mathrm{SiC}$ and $\mathrm{Al} 2 \mathrm{O} 3$ added
}

esra kul ( $\nabla$ esra.kul@atauni.edu.tr)

Ataturk Universitesi Dis Hekimligi Fakultesi

faruk yeşildal

Agri Ibrahim Cecen Universitesi

Keywords:

Posted Date: August 22nd, 2019

DOl: https://doi.org/10.21203/rs.2.13389/v1

License: (c) (1) This work is licensed under a Creative Commons Attribution 4.0 International License.

Read Full License 


\section{Abstract}

The authors have requested that this preprint be removed from Research Square. 